\title{
Biometric relationships for commercially important penaeid shrimp species on the east coast of the Gulf of California
}

\author{
Carlos H. Rábago-Quiroz ${ }^{1}$, Viridiana Y. Zepeda-Benítez ${ }^{2}$ \\ Juana López-Martínez ${ }^{3} \&$ Jesús G. Padilla-Serrato ${ }^{4}$ \\ ${ }^{1}$ Instituto Nacional de Pesca y Acuacultura, Centro Regional de Investigación Acuícola y Pesquera \\ La Paz, Baja California Sur, México \\ ${ }^{2}$ Instituto Nacional de Pesca y Acuacultura, Dirección General Adjunta de Investigación Pesquera en el \\ Pacífico, Ensenada, Baja California, México \\ ${ }^{3}$ Centro de Investigaciones Biológicas del Noroeste, Unidad Sonora, Campus Guaymas \\ Guaymas, Sonora, México \\ ${ }^{4}$ Cátedras CONACYT, Facultad de Ecología Marina, Universidad Autónoma de Guerrero \\ Guerrero, México \\ Corresponding author: Carlos H. Rábago-Quiroz (carlos.rabago@inapesca.gob.mx)
}

\begin{abstract}
Biometric relationships were estimated for the three most important shrimp species on the coasts of the Gulf of California, Mexico. Individuals were obtained from six lagoon systems, and offshore sites along the east coast of the Gulf of California, mainly in the state of Sonora, between March and September of 2015 and 2016. A total of 25,764 individuals of Penaeus stylirostris, Penaeus vannamei and Farfantepenaeus californiensis were analyzed; the length and weight regression for the females, males and combined sexes showed a high correlation between variables. Additionally, some statistically significant differences were found in the linear length and weight relationships $(P<0.05)$ between sexes. This study reports the length-weight parameters for a key site of the shrimp fishery, it covers a wide range of sizes for each species and was based on the stages late inshore juvenile and offshore of the shrimp lifecycle; as such, this study provides useful information for future estimations of indispensable parameters for stock assessment analyses.
\end{abstract}

Keywords: Penaeidae; blue shrimp; brown shrimp; length-weight; Sonora; Mexico

Penaeid shrimps have commercial importance in tropical and subtropical seas, and the annual world catch is estimated at $1 \mathrm{Mt}$ per year, with the majority harvested by trawlers (Kelleher, 2005; Gillett, 2008). The shrimp fishery is one of the most important fisheries in Mexico because it provides important social and economic benefits. On the Pacific coast, Sonora and Sinaloa support the main part of the fishery within the Gulf of California (e.g., 85\% of the total catch). The brown shrimp Farfantepenaeus californiensis (Holmes, 1990), blue shrimp Penaeus stylirostris Stimpson, 1871 and white shrimp Penaeus vannamei Boone, 1931 are the three most important commercial species that are exploited at various stages of life cycle by artisanal and industrial fisheries (Gillett, 2008; Dubay et al., 2010; CONAPESCA, 2017). F. californiensis constitutes the base of the offshore catch (e.g., 70-80\% of the industrial fleet), while $P$. stylirostris and $P$. vannamei comprise the base of the shrimp fishery in bays and coastal lagoons (i.e., the artisanal fleet). In this multi-specific fishery, the management strategy consists of setting a seasonal closure between April and August to prevent growth overfishing during the spawning season. The seasonal closure help to decreases the catch of juveniles during the recruitment period, included in the main regulatory measures (NOM-002-PESC-1993). This Mexican Official Standard has provisions for control and reduction of fishing effort (number of boats), closed seasons and closed areas (Gillett, 2008).

The information on the length-weight relationships is necessary to determine the conversion equations from growth in length to growth in weight, which will

Corresponding editor: Leonardo Abitia 
be used for the estimation of indispensable parameters in the stock assessment analysis (Al Nahdi et al., 2016; Freitas et al., 2017). In penaeid studies, measurements of certain lengths, rather than weights, are usually recorded in samplings campaigns. Globally, some authors have provided biometrics relationships for commercial penaeid shrimp, particularly Penaeus genus (Fontaine \& Neal, 1971; Rodríguez de la Cruz, 1981; Chu et al., 1995; Pérez-Castañeda \& Defeo, 2002; López-Martínez et al., 2005; Ramos-Cruz, 2012). However, in some important global shrimp catch areas, there is no information about the biometric relationships of these commercial shrimp (Penaeus genus), or the information comes from an old information.

Even though the Gulf of California is the most important shrimp catch area for Mexico, there is little information about the biometric relationships of these commercial shrimps. The existent information about this topic comes from small sample sizes, samples collected at certain times in the species life cycles or from only commercial catches (Menz \& Bowers, 1980; Rodríguez de la Cruz, 1981; López-Martínez et al., 2005). This study presents the biometric relationships for the three commercially important penaeid shrimp (e.g., F. californiensis, $P$. stylirostris and $P$. vannamei) on the east coast of the Gulf of California. With the purpose to cover a wide range of sizes for each shrimp species, the length and weight information coming from two years of intense sampling (2015-2016). Additionally, sampling was conducted using different fishing gears and different areas, based on the life cycle of each species.

\section{Collection of specimens}

Shrimp samples were collected from March to September in 2015 and 2016 (when the shrimp fishing season is closed) along the east coast of the Gulf of California, mainly in the state of Sonora (Fig. 1). Specifically, monthly biological surveys (from March to September) were conducted inside and outside each of six lagoon systems (e.g., Bahía de Kino, Las Guásimas, Bahía de Lobos, El Tobari, Yavaros and Agiabampo). The sampling stations correspond to those established and sampled annually by the Instituto Nacional de Pesca and Acuacultura (INAPESCA, a Mexican Fisheries Research Institution) to assess the shrimp populations. Sampling stations were spread across the shrimp fishing grounds at depths ranging from 0.5 to $8 \mathrm{~m}$ deep. The fishing gears used in these surveys were shrimp trawl nets (8-9 $\mathrm{m}$ float line and 35 $\mathrm{mm}$ liner at the codend), gillnets (44,50,57 and $60 \mathrm{~mm}$ mesh size) and cast nets (25 to $44 \mathrm{~mm}$ mesh size).
Moreover, during July-August of 2015, 2016, research cruises were conducted in the coastal waters of Sonora (7 to $54 \mathrm{~m}$ deep), from Bahía de Kino to Agiabampo (Fig. 1). These sampling stations also correspond to those established by INAPESCA. The fishing gears deployed from the vessels consisted of paired shrimp trawls nets ( $30.5 \mathrm{~m}$ float line and 45-50 $\mathrm{mm}$ mesh size), which are typical of the commercial shrimp fleet in the Gulf of California.

\section{Data measurement}

Shrimp were separated by species ( $F$. californiensis, $P$. stylirostris and $P$. vannamei) (Ma et al., 2011). Their abdominal and total length (i.e., from the tip of the rostrum to the tip of the telson in the extended specimen, in $\mathrm{mm}$ ) was measured to the nearest millimeter with an ichthyometer, and total and abdominal weight was recorded to the nearest $0.01 \mathrm{~g}$ using an electronic balance.

\section{Statistical analysis}

The abdominal length/total length (AL/TL) relationships for the three shrimp species were estimated separately for males and females and for both sexes, and data from 2015 and 2016 were assessed using the following expressions: $\mathrm{TL}=a+b \times \mathrm{AL}$, where TL is the total length $(\mathrm{mm}), \mathrm{AL}$ is the abdominal length $(\mathrm{mm}), a$ is the intercept and $b$ is the slope.

The total-length/total-weight (TL/TW) and abdominal-length/abdominal-weight (AL/AW) relationships were estimated for males and females separately, and then for both sexes together. Data from 2015 and 2016 were assessed using the equations: TW $=a \times \mathrm{TL}^{b}$ and $\mathrm{AW}=a \times \mathrm{AL}^{b}$, where $\mathrm{W}$ is the weight (total or abdominal), $\mathrm{L}$ is the length (total or abdominal), $a$ is the coefficient of proportionality and $b$ is the coefficient of allometry. These equations assume that the relative body proportions of the individuals increase based on the last two parameters. The equation was linearized: $\log \mathrm{W}=a+b \times \log \mathrm{L}$. Log-log plots of the length-weight pairs were created to identify outliers, and extreme outliers were excluded from the analysis (Froese et al., 2006). For all equations, the coefficient of determination $\left(\mathrm{R}^{2}\right)$ was used as the index of the strength of the linear association, and the 95\% confidence limits for $a$ and $b$ were calculated.

Statistically significant differences in linear relationships between sexes were evaluated through a oneway covariance analysis (ANCOVA), where the dependent variable was the weight and the covariate the length. ANCOVA was used once the assumptions of slope homoscedasticity were found, and after data were log- transformed (Zar, 2009). 


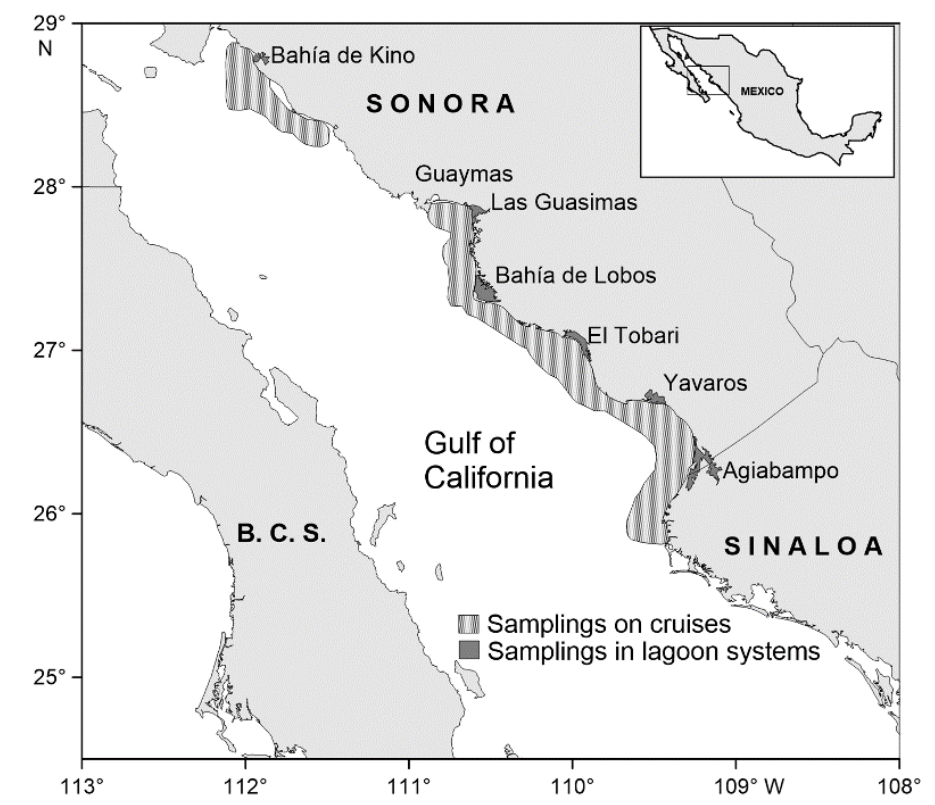

Figure 1. Study area where the shrimps were collected inside and outside of six lagoon systems (0.5-8 $\mathrm{m}$ deep) and offshore (7-54 $\mathrm{m}$ deep), along the east coast of the Gulf of California.

Table 1. Sex ratio (F:M), minimum and maximum length and the basic statistics for the three shrimp species (Penaeus stylirostris, Penaeus vannamei and Farfantepenaeus californiensis) used in the AL/TL regression analyses. Mean, median and standard deviation (SD) were calculated using only for the total length data. F: females, M: males.

\begin{tabular}{lcrccccc}
\hline Species & Sex & \multicolumn{1}{c}{$\mathrm{n}$} & AL $(\mathrm{mm})$ & TL $(\mathrm{mm})$ & Mean & Median & SD \\
\hline \multirow{2}{*}{ P. stylirostris } & $\mathrm{F}$ & 4011 & $28-153$ & $46-242$ & 135 & 140 & 31.76 \\
& $\mathrm{M}$ & 2722 & $29-137$ & $47-212$ & 143 & 147 & 23.07 \\
F. californiensis & $\mathrm{F}$ & 10822 & $31-145$ & $50-223$ & 132 & 133 & 35.32 \\
& $\mathrm{M}$ & 7280 & $32-138$ & $50-207$ & 117 & 119 & 22.35 \\
P. vannamei & $\mathrm{F}$ & 608 & $32-142$ & $48-215$ & 121 & 113 & 32.73 \\
& $\mathrm{M}$ & 321 & $44-135$ & $78-196$ & 127 & 123 & 27.31 \\
\hline
\end{tabular}

A total of 25,764 individuals of P. vannamei (929), $P$. stylirostris $(6,733)$ and $F$. californiensis $(18,102)$ were analyzed. The sex ratio, minimum and maximum length (abdominal and total length), maximum length and weight (total-length and total-weight), and basic statistics for the three shrimp species are presented in Tables 1 and 2. The length-frequency distributions of measured shrimp were separated by species and sex, and used by the length regression analysis; these results are shown in Figure 2. It can be observed that there was a wide range of sizes for each shrimp species, which denotes intense sampling with different fishing gears and different samplings areas, based on the stages late inshore juvenile and offshore of the shrimp's lifecycle.

The length regressions for females, males and combined data for the three shrimp species (i.e., blue, brown and white) showed high correlation according to the coefficients of determination $\left(R^{2}>0.970\right.$ in all cases). Statistically significant differences in the linear length relationships $(P<0.05)$ were found between sexes for the three shrimp species (Table 3 ).

A total of 10,057 individuals of $P$. vannamei (451), $P$. stylirostris $(3,834)$ and $F$. californiensis $(5,772)$ were used for the length-weight relationship analysis. The length-frequency distribution of measured shrimp was separated by species and sex, and used by the lengthweight regression analysis; these results are shown in Figure 2.

The weight regressions for females, males and both sexes of the three shrimp species (i.e., blue, brown and white) showed high correlations between variables, according to the coefficients of determination $\left(\mathrm{R}^{2}>\right.$ 0.970 in all cases; Table 4). Statistically significant differences in the log-linear weight relationships $(P<$ 0.05 ) were found between sexes for $F$. californiensis. $P$. stylirostris showed a significant difference between sexes in the total length-total weight relationship, but there was no significant difference between sexes in the 

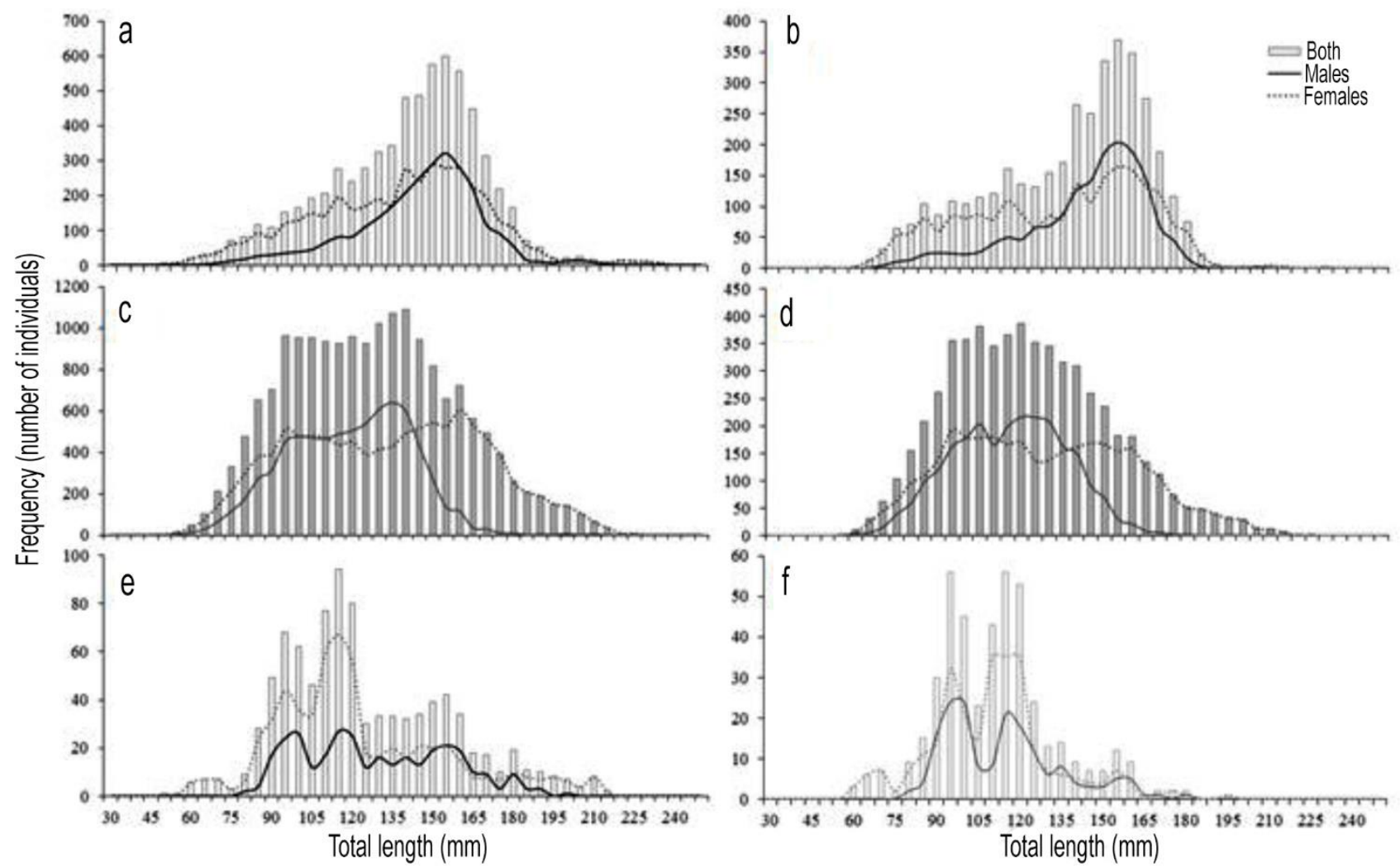

Figure 2. Sizes distribution for a-b) Penaeus stylirostris, c-d) Farfantepenaeus californiensis, and e-f) Penaeus vannamei used in the $\mathrm{AL} / \mathrm{TL}(\mathrm{a}, \mathrm{c}, \mathrm{e})$ and $\mathrm{L} / \mathrm{W}(\mathrm{b}, \mathrm{d}, \mathrm{f})$ regression analyses.

Table 2. Sex ratio (F:M), minimum and maximum total-length $(\mathrm{mm}) /$ total-weight $(\mathrm{g})$, and the basic statistics for the three shrimp species (Penaeus stylirostris, Penaeus vannamei and Farfantepenaeus californiensis) used in the TL/TW regression analyses. F: females, M: males.

\begin{tabular}{lcccccccccc}
\hline Species & Sex & $\mathrm{n}$ & $\mathrm{TL}(\mathrm{mm})$ & Mean & Median & SD & TW $(\mathrm{g})$ & Mean & Median & SD \\
\hline \multirow{2}{*}{ P. stylirostris } & $\mathrm{F}$ & 2191 & $57-226$ & 131 & 137 & 31.27 & $1.2-89$ & 20.4 & 19.2 & 13.68 \\
& $\mathrm{M}$ & 1643 & $62-205$ & 141 & 147 & 23.04 & $2.0-73$ & 23.6 & 24.3 & 10.59 \\
\multirow{2}{*}{ F. californiensis } & $\mathrm{F}$ & 3341 & $55-222$ & 127 & 125 & 32.78 & $1.3-103$ & 20.5 & 16.0 & 15.46 \\
& $\mathrm{M}$ & 2431 & $57-207$ & 114 & 115 & 20.67 & $1.5-81$ & 13.1 & 12.1 & 6.93 \\
\multirow{2}{*}{ P. vannamei } & $\mathrm{F}$ & 277 & $57-195$ & 108 & 109 & 22.28 & $1.6-66$ & 11.3 & 10.3 & 8.18 \\
& $\mathrm{M}$ & 174 & $78-177$ & 112 & 111 & 20.66 & $2.9-45$ & 12.4 & 10.9 & 8.39 \\
\hline
\end{tabular}

abdominal length/abdominal weight relationship $(P>$ $0.05)$. Finally, $P$. vannamei did not show significant differences between sexes in any log-linear weight relationships $(P>0.05)$.

This study conducted intense sampling with different fishing gears and different samplings areas; the design attempted to cover most of the habitat for each shrimp species based on the stages late inshore juvenile and offshore of shrimp's lifecycle. With this method of analyzing information, the effect of selectivity of single fishing gear was reduced, which causes having a narrow range of sizes, and also generated less accurate estimates of parameters derived from that size structure (López-Martínez et al., 2005).
As a consequence, there is a wide range of sizes and weights for the three shrimp species (Tables 1-4), which provides more robust results.

Considerable variability in the biometric relationships may occur within shrimp species; this variability depends on the season, the differences in environmental conditions or the population; under this premise, the knowledge of specific biometric relationships for species and area must be assessed.

These studies are useful for estimating some measure of weight or some corporal measure that corresponds to a given length, and this provides a quantitative measure of biomass as well as other impor- 
Table 3. Summary of the length regression for females only, males only and combined data for the three shrimp species (Penaeus stylirostris, Penaeus vannamei and Farfantepenaeus californiensis). F and $P$ are values of the covariance analysis.

\begin{tabular}{|c|c|c|c|c|c|c|}
\hline \multirow{2}{*}{ Species/Sex } & \multirow{2}{*}{ Equation } & \multicolumn{2}{|c|}{ Confidence interval 95\% } & \multirow{2}{*}{$\mathrm{R}^{2}$} & \multirow{2}{*}{$\begin{array}{c}\mathrm{F} \\
\text { (ANCOVA) }\end{array}$} & \multirow{2}{*}{$\begin{array}{c}P \\
\text { (ANCOVA) }\end{array}$} \\
\hline & & $a$ & $b$ & & & \\
\hline \multicolumn{7}{|l|}{ P. stylirostris } \\
\hline Females & $\mathrm{TL}=$ & $1.487 \pm 0.005$ & $10.404 \pm 0.460$ & 0.986 & 121.471 & $<0.0001$ \\
\hline Males & $\mathrm{TL}=$ & $1.430 \pm 0.008$ & $14.398 \pm 0.725$ & 0.978 & & \\
\hline Both & $\mathrm{TL}=$ & $1.467 \pm 0.004$ & $11.660 \pm 0.391$ & 0.984 & & \\
\hline \multicolumn{7}{|c|}{ F. californiensis } \\
\hline Females & $\mathrm{TL}=$ & $0.635 \pm 0.001$ & $1.312 \pm 0.154$ & 0.991 & 415.632 & $<0.0001$ \\
\hline Males & $\mathrm{TL}=$ & $1.498 \pm 0.004$ & $2.856 \pm 0.343$ & 0.983 & & \\
\hline Both & $\mathrm{TL}=$ & $0.673 \pm 0.001$ & $1.241 \pm 0.123$ & 0.989 & & \\
\hline \multicolumn{7}{|l|}{ P. vannamei } \\
\hline Females & $\mathrm{TL}=$ & $1.477 \pm 0.010$ & $4.332 \pm 0.863$ & 0.992 & 5.995 & 0.015 \\
\hline Males & $\mathrm{TL}=$ & $1.398 \pm 0.017$ & $10.073 \pm 1.534$ & 0.986 & & \\
\hline Both & $\mathrm{TL}=$ & $1.452 \pm 0.009$ & $6.025 \pm 0.784$ & 0.989 & & \\
\hline
\end{tabular}

Table 4. Summary of the weight regression for females only, males only and combined data for the three shrimp species (Penaeus stylirostris Penaeus vannamei and Farfantepenaeus californiensis). $\mathrm{F}$ and $P$ are values of the covariance analysis.

\begin{tabular}{|c|c|c|c|c|c|c|}
\hline \multirow{2}{*}{ Species/Sex } & \multirow{2}{*}{ Equation } & \multicolumn{2}{|c|}{ Confidence interval 95\% } & \multirow[b]{2}{*}{$\mathrm{R}^{2}$} & \multirow{2}{*}{$\begin{array}{c}\mathrm{F} \\
\text { (ANCOVA) }\end{array}$} & \multirow{2}{*}{$\begin{array}{c}P \\
\text { (ANCOVA) }\end{array}$} \\
\hline & & $a$ & $b$ & & & \\
\hline \multicolumn{7}{|l|}{ P. stylirostris } \\
\hline \multirow{2}{*}{ Females } & $\log \mathrm{TW}=$ & $-13.168 \pm 0.078$ & $3.278 \pm 0.016$ & 0.986 & 7.453 & 0.006 \\
\hline & $\log \mathrm{AW}=$ & $-11.412 \pm 0.063$ & $3.129 \pm 0.014$ & 0.987 & 2.086 & 0.149 \\
\hline \multirow{2}{*}{ Males } & $\log \mathrm{TW}=$ & $-13.214 \pm 0.108$ & $3.290 \pm 0.021$ & 0.981 & & \\
\hline & $\log \mathrm{AW}=$ & $-11.259 \pm 0.076$ & $3.094 \pm 0.017$ & 0.986 & & \\
\hline \multirow{2}{*}{ Both } & $\log \mathrm{TW}=$ & $-13.193 \pm 0.061$ & $3.288 \pm 0.012$ & 0.985 & & \\
\hline & $\log \mathrm{AW}=$ & $-11.356 \pm 0.047$ & $3.116 \pm 0.010$ & 0.987 & & \\
\hline \multicolumn{7}{|c|}{ F. californiensis } \\
\hline \multirow{2}{*}{ Females } & $\log \mathrm{TW}=$ & $-5.233 \pm 0.022$ & $3.072 \pm 0.010$ & 0.989 & 152.834 & $<0.0001$ \\
\hline & $\log \mathrm{AW}=$ & $-4.736 \pm 0.020$ & $3.015 \pm 0.010$ & 0.989 & 181.686 & $<0.0001$ \\
\hline \multirow{2}{*}{ Males } & $\log \mathrm{TW}=$ & $-5.071 \pm 0.035$ & $2.987 \pm 0.017$ & 0.978 & & \\
\hline & $\log \mathrm{AW}=$ & $-4.588 \pm 0.035$ & $2.928 \pm 0.018$ & 0.974 & & \\
\hline \multirow{2}{*}{ Both } & $\log \mathrm{TW}=$ & $-5.213 \pm 0.018$ & $3.059 \pm 0.009$ & 0.986 & & \\
\hline & $\log \mathrm{AW}=$ & $-4.718 \pm 0.018$ & $3.002 \pm 0.009$ & 0.985 & & \\
\hline \multicolumn{7}{|l|}{ P. vannamei } \\
\hline \multirow{2}{*}{ Females } & $\log \mathrm{TW}=$ & $-5.427 \pm 0.089$ & $3.155 \pm 0.044$ & 0.986 & 0.201 & 0.654 \\
\hline & $\log \mathrm{AW}=$ & $-4.992 \pm 0.093$ & $3.143 \pm 0.050$ & 0.983 & 0.169 & 0.681 \\
\hline \multirow{2}{*}{ Males } & $\log \mathrm{TW}=$ & $-5.730 \pm 0.118$ & $3.303 \pm 0.057$ & 0.986 & & \\
\hline & $\log \mathrm{AW}=$ & $-4.868 \pm 0.163$ & $3.078 \pm 0.057$ & 0.984 & & \\
\hline \multirow{2}{*}{ Both } & $\log \mathrm{TW}=$ & $-5.519 \pm 0.071$ & $3.201 \pm 0.035$ & 0.986 & & \\
\hline & $\log \mathrm{AW}=$ & $-4.939 \pm 0.070$ & $3.115 \pm 0.037$ & 0.983 & & \\
\hline
\end{tabular}

tant biological aspects as, such as describing the growth pattern by evaluating the allometric coefficients and determining morphometric comparisons and stock structures. Further, deviations from this general relationship have been used to monitor the relative state of health of a given population (Cone, 1989; Ecoutin et al., 2005; Froese, 2006). The length and weight regressions in females, males and combined data for the three shrimp species showed high correlation (R2 > 0.970 in all cases); suggesting a good adjustment of the data; this may be a consequence of the sample size and wide range of sizes and weights that were analyzed for each species in this study. Therefore, the use of the length-weight relationships presented here may not be limited to narrow ranges of length. In addition, the extensive sampling areas cover most of the habitat for each species based on the stages late inshore juvenile and offshore of the shrimp's lifecycle.

$F$. californiensis and P. stylirostris showed significant differences according to the total-length/total- 
weight relationship between sexes; however, no significant differences were observed in P. stylirostris about abdominal-length/abdominal-weight relationship between sexes. Similarly, P. vannamei did not show significant differences at any of the log-linear weight relationships between sexes. Anderson \& Lindner in Fontaine \& Neal (1971), noted that mature shrimp were heavier than immature individuals of the same length and that this difference caused seasonal changes in the length-weight relationship. Chu et al. (1995) mentioned that mature female of some penaeids (e.g., Penaeus merguiensis, $P$. longistylus, $P$. latisulcatus and Metapenaeus ensis) were commonly heavier than immature females of the same length.

In this research, the lack of significant differences in the log-linear weight relationships between sexes of $P$. stylirostris and $P$. vannamei is attributed to the fact that the overwhelming majority (>95\%) of shrimp analyzed (e.g., females) were immature individuals. In contrast, in F. californiensis, $66 \%$ of the measured individuals were immature and $34 \%$ mature; this is due to the breeding strategy of this species, which occurs throughout whole year, individuals are smaller than the rest of the species (Leal-Gaxiola et al., 2001; RomeroSedano et al., 2004), and mature individuals can be caught in lagoon systems and coastal waters during the whole year. According to the sampling dates in our study (e.g., March to September in lagoon systems and July to August in offshore sites), and considering the life cycles of $P$. stylirostris and $P$. vannamei, it was expected to catch mostly immature individuals. From June to September, the blue and white shrimp (e.g., juvenile and subadults) use lagoon systems as nursery areas, and individuals are still subadults when they start migrating to coastal waters (e.g., September). These species show interannual variability of the reproductive period, with a more intense spawning peak (e.g., a single cohort is more abundant in the catch) and it occurs offshore (Leal-Gaxiola et al., 2001; LópezMartínez et al., 2005; Rivera-Velázquez et al., 2008); thus, we were not able to catch mature individuals in lagoon systems and coastal waters throughout the year. About linear length relationships, significant differences were found between sexes of the three shrimp species evaluated in this study. Fontaine \& Neal (1971) detected similar results for white and brown shrimp in the Gulf of Mexico (Texas and Florida).

This research emphasizes the importance of biometric relationships studies for commercial fisheries in different ground fishing areas, useful information for future estimations of indispensable parameters for stock assessment analyses.

\section{ACKNOWLEDGMENTS}

Financial support was received from INAPESCA (CRIAP- Guaymas, Sonora), "Evaluación y Manejo del Recurso Camarón en Sonora, 2015 y 2016" grants. The first author is grateful to Heraclio Cervantes and María de Jesús Anguiano who helped with sampling and the Comisión Nacional de Acuacultura y Pesca (CONAPESCA) for the Permisos de Pesca de Fomento PPF/DGOPA-066/15 and PPF/DGOPA-105/16.

\section{REFERENCES}

Al Nahdi, A., Garcia de Leaniz, C. \& King, A.J. 2016. Spatio-temporal variation in length-weight relationships and condition of the ribbonfish Trichiurus lepturus (Linnaeus, 1758): implications for fisheries management. Plos One, 11(8): e0161989.

Chu, K.H., Chen, Q.C., Huang, L.M. \& Wong, C.K. 1995. Morphometric analysis of commercially important penaeid from the Zhujiang estuary, China. Fisheries Research, 23: 83-93. doi: 10.1016/0165-7836(94)00342-T

Comisión Nacional de Acuacultura y Pesca (CONAPESCA). 2017. Anuario Estadístico de Acuacultura y Pesca 2017. Comisión Nacional de Acuacultura y Pesca, Mazatlán.

Cone, R.S. 1989. The need to reconsider the use of condition indices in fishery science. Transactions of the American Fisheries Society, 118: 510-514.

Dubay, K., Tokuoka, S. \& Gereffi, G. 2010. A value chain analysis of the Sinaloa, Mexico shrimp fishery. Durham Duke University, Durham.

Ecoutin, J.M., Albaret, J.J. \& Trape, S. 2005. Lengthweight relationships for fish populations of a relatively undisturbed tropical estuary: the Gambia. Fisheries Research, 72(2-3): 347-351.

Fontaine, C.T. \& Neal, R.A. 1971. Length-weight relations for three commercial important shrimp of the Gulf of Mexico. Transactions of the American Fisheries Society, 100(3): 584-586.

Freitas, T.M.D., Souza, J.B.D., Prudente, B.D. \& Montag, L.F.D. 2017. Length-weight relationship in ten fish species from the Nhamundá River, the Amazon Basin, Brazil. Acta Amazonica, 47(1): 75-78.

Froese, R. 2006. Cube law, condition factor, and weightlength relationships: history, meta-analysis, and recommendations. Journal of Applied Ichthyology, 22(4): 241-253.

Gillett, R. 2008. Global study of shrimp fisheries. FAO Fisheries Technical Paper 475, Rome.

Kelleher, K. 2005. Discards in the world's marine fisheries. An update. FAO Fisheries Technical Paper 470, Rome. 
Leal-Gaxiola, A., López-Martínez, J., Chávez, E.A., Hernández-Vázquez, S. \& Méndez-Tenorio, F. 2001. Interannual variability of the reproductive period of the brown shrimp, Farfantepenaeus californiensis (Holmes, 1900) (Decapoda, Natantia). Crustaceana, 74: 839-851.

López-Martínez, J., Rábago-Quiroz C., Nevárez-Martínez M.O., García-Juárez A.R., Rivera-Parra, G. \& ChávezVillalba, J. 2005. Growth, reproduction, and size at first maturity of blue shrimp, Litopenaeus stylirostris (Stimpson, 1874) along the east coast of the Gulf of California, Mexico. Fisheries Research, 71: 93-102. doi: 10.1016/j.fishres.2004.06.004

Ma, K.Y., Chan, T.Y. \& Chu, K.H. 2011. Refuting the sixgenus classification of Penaeus s.l. (Dendrobranchiata, Penaeidae): a combined analysis of mitochondrial and nuclear genes. Zoologica Scripta, 40: 498-508.

Menz, A. \& Bowers, A.B. 1980. Bionomics of Penaeus vannamei boone and Penaeus stylirostris Stimpson in a lagoon on the Mexican Pacific Coast. Estuarine and Coastal Marine Science, 10: 685-697. doi: 10.1016/ S0302-3524(80)80096-X

Pérez-Castañeda, R. \& Defeo, O. 2002. Morphometric relationships of penaeid shrimps in a coastal lagoon spatio-temporal variability and management implications. Estuaries, 25: 282-287.

Received: 20 April 2018; Accepted: 11 June 2019
Ramos-Cruz, S. 2012. Aspectos biológicos y poblacionales del camarón blanco Litopenaeus vannamei (Boone 1931), durante la veda de 2006 en el Golfo de Tehuantepec, México. Oceánides, 27: 11-24.

Rivera-Velásquez, G., Soto, L.A., Salgado-Ugarte, I.H. \& Naranjo, E.J. 2008. Growth, mortality and migratory pattern of white shrimp (Litopenaeus vannamei, Crustacea, Penaeidae) in the Carretas-Pereyra coastal lagoon system, Mexico. Revista de Biología Tropical, 56(2): 523-533.

Rodríguez de la Cruz, M.C. 1981. Aspectos pesqueros del camarón de alta mar en el Pacífico Mexicano. Ciencia Pesquera, 1: 1-19.

Romero-Sedano, J., Aragón-Noriega, E.A., ManzanoSarabia, M.M., Salinas-Zavala, C.A. \& García-Juárez, A.R. 2004. Periodo reproductivo del camarón café Farfantepenaeus californiensis (Holmes, 1900) en la laguna costera de Agiabampo, Sonora/Sinaloa, México. Ciencias Marinas, 30: 465-475.

Zar, J.H. 2009. Biostatistical analysis. Pearson Education, Harlow. 